\title{
INFLUENCE OF COPING STRATEGIES ON THE STUDENT'S WELL-BEING IN CONDITIONS OF DISTANCE LEARNING
}

\author{
Alyona Vavilova \\ Borys Grinchenko Kyiv University, Ukraine
}

\begin{abstract}
The article is devoted to the study of student's coping strategies influence on the level of their subjective well-being in conditions of distance learning. It was found that student's coping strategies have an impact on the level of their psychological comfort. Using regression analysis it was revealed that the variability of student's life well-being is determined by the following coping strategies: positive self-esteem; responsibility; planning; escape and selfcontrol. It was developed the typology of students in the conditions of distance education, which includes such indicators of dominant coping strategies: the level of psychological comfort, dominant coping and measure of stress tolerance. According to the certain typology, three types of students were defined: 1) adaptive type (high indicators of well-being, high indicators of tolerance to stress, dominant strategies "self-esteem", “responsibility" and "planning”); 2) maladaptive type (low indicators of well-being, low indicators of tolerance to stress, dominant coping "escape"); 3) average adaptive type (average indicators of well-being, average indicators of tolerance to stress; dominant strategies "responsibility", "self-control", low indicators of coping "positive self-esteem"). The results of the study indicate that students who are best adapted to distance learning and have a high level of psychological comfort tend to evaluate themselves positively, treat work responsibly, plan their studies and have an average level of self-control.
\end{abstract}

Keywords: adaptation, coping strategies, distance learning, student well-being.

\section{Introduction}

In the last few years, modern society has faced global challenges that have significantly affected society life. One of such challenges was the COVID-19 pandemic, which led to the introduction of quarantine restrictions in various fields, including university education. To continue the learning process during quarantine, universities transformed to distance learning.

Distance education became a non-standard form of education for both teachers and students. The new format of education caused psychological discomfort and the need to adapt to non-traditional life realities. In such circumstances, students have a problem choosing certain coping strategies that would help them continue to receive their professional qualifications. An 
important factor of choosing such coping strategies was to provide quality education and, at the same time, psychological comfort, because the new way of university studying caused anxiety and difficulties in self-organization, which negatively influenced the level of emotional well-being. Therefore, the purpose of this study was to analyze the actual problem of choosing effective adaptive ways of students to distance learning, which supports their subjective well-being.

Coping strategies allow coping with various life difficulties and are relevant in stressful or unusual circumstances. The study of coping is associated with the analysis of personality regulation and self-regulation, personal development and the ability to use internal resources. By studying the dominant coping strategies, it is possible to understand the level of adaptability of human behavior (stress management), which can be a factor of reducing or increasing productivity in stressful circumstances (Kriukova, 2008). Therefore, early detection of maladaptive coping is an important practical task of providing psychological assistance to people with life difficulties (Galatzer-Levy, Burton, \& Bonanno, 2012).

There are many approaches to determining the types and structure of coping strategies. Many authors agree in their classification that copings are divided into adaptive (help person to cope with stress) and maladaptive (negatively affect human life). Adaptive coping strategies are often associated with problem solving, a rational approach, the ability to use one's own resources and receive social support. Maladaptive strategies include escape from problems, emotional focus on difficulties, and dependence on social support (Skinner, Edge, Altman, \& Sherwood, 2003; Cheng, Lau, \& Chan, 2014).

According to A. Dermanova, coping behavior is especially important in early adulthood, because it is a mechanism of personality development at this age (Dermanova, 2011). As a result of the fact that young people cope with difficult life situations, there are positive personality changes that lead to a higher level of personality functioning. The period of early adulthood connects exactly with the student years of study, so the issue of coping strategies is relevant for students.

Many researchers focus on the study of student's coping strategies in relevant learning situations, such as exam situations. The exam is a stress factor for students, which involves checking the success of mastering the subject and it is one of the main causes of mental stress (Olennikova, 2015). Increased stress during the exam period has a significant impact on the mental and physical health of students creates risks of reduced efficiency, emotional problems and physical health disorders (Arendarchuk, 2015). Adaptive coping strategies in this case are regulatory mechanisms to overcome stress, which can reduce the stressful impact of the situation, save mental and physical health.

Student mechanisms for managing with stress can be aimed at solving a specific problem or reducing the negative impact on personality psychological 
comfort. Problem-oriented strategies involve active behaviors intent at overcoming and purposeful control over the stressors` impact. Emotionally focused strategies are associated with different psychological protection mechanisms, which intent to reducing the emotional discomfort (Kyreeva, 2012).

The choice of a specific coping strategy or group of copings affects student self-efficacy, which is considered one of the most important factors of student involvement, cognitive interest and academic success (Freire, Mar Ferradás, Regueiro, \& Rodríguez 2020). Thus, student coping strategies not only minimize distress and prevent psychological problems, but also ensure success and increase productivity in non-standard conditions. Students who have successfully adapted to stressful conditions are able to develop their professional skills and use effective ways to overcome stress in future activities (Deasy, Coughlan, \& Pironom, 2014).

\section{Methodology}

To study the influence of coping strategies on the students ' well-being in conditions of distance learning three psychodiagnostic methods were selected: "Scale of Subjective Well-being", "Ways of Coping Checklist" by Folkman \& Lazarus in adaptation of T. Krukova and "New Stress Tolerance Questionnaire" by $\mathrm{T}$. Kornilova.

The method "Subjective Well-being Scale" allows to differentiate the emotional component of students subjective well-being, which is based on an analysis of the following criteria: tension and sensitivity, psycho-emotional symptoms, mood changes, significance of social environment, life satisfaction (Fetyskyn, Kozlov, \& Manuilov, 2002). This method was used in accordance with purpose of the study - to find out how the choice of certain coping strategies influence on student`s emotional comfort in connection with being in a distance learning situation.

The "Ways of Coping Checklist" by Folkman \& Lazarus was used to identify the following types of coping strategies: confrontation, distancing, self-control, seeking social support, responsibility, escape-avoidance, problem-solving planning, and positive self-esteem (Kriukova \& Kuftiak, 2007).

These coping strategies help to cope with life's difficulties by changing cognitive and behavioral patterns to adapt for specific environmental requirements. Based on the results of this method, the most effective student`s coping strategies for distance learning were analyzed. The level of subjective well-being was determined as an indicator of the coping strategy effectiveness.

The last, third method "New Stress Tolerance Questionnaire", was used to determine the ability to keep stress resistance in the stressful conditions 
(Kornylova, 2010). For students, such a condition is the situation of a new format of distance learning due to the restriction of quarantine.

In order to investigate, how students' coping strategies influence the level of their subjective well-being in conditions of distance learning, 52 students (19 men and 33 women) aged 19 - 21 years old were selected. Students studied at 2 - 4 courses of such specialties as: social pedagogy, practical psychology and speech therapy. First-year students were not included in the study due to the condition that for them studying at the university is already an adaptation period for which distance learning is imposed. Therefore, their adaptation to university may be an additional variable, which can distort the results of the study.

The research was conducted during the period of quarantine and the distance learning caused by it, which was an unusual and stressful situation for the studied students and required updating of coping strategies.

\section{Research Results and Discussion}

At the first stage of the study, students passed the method "Ways of Coping Checklist", being in a distance-learning environment, which allowed to identify the most common coping strategies in the student sample (Figure 1).

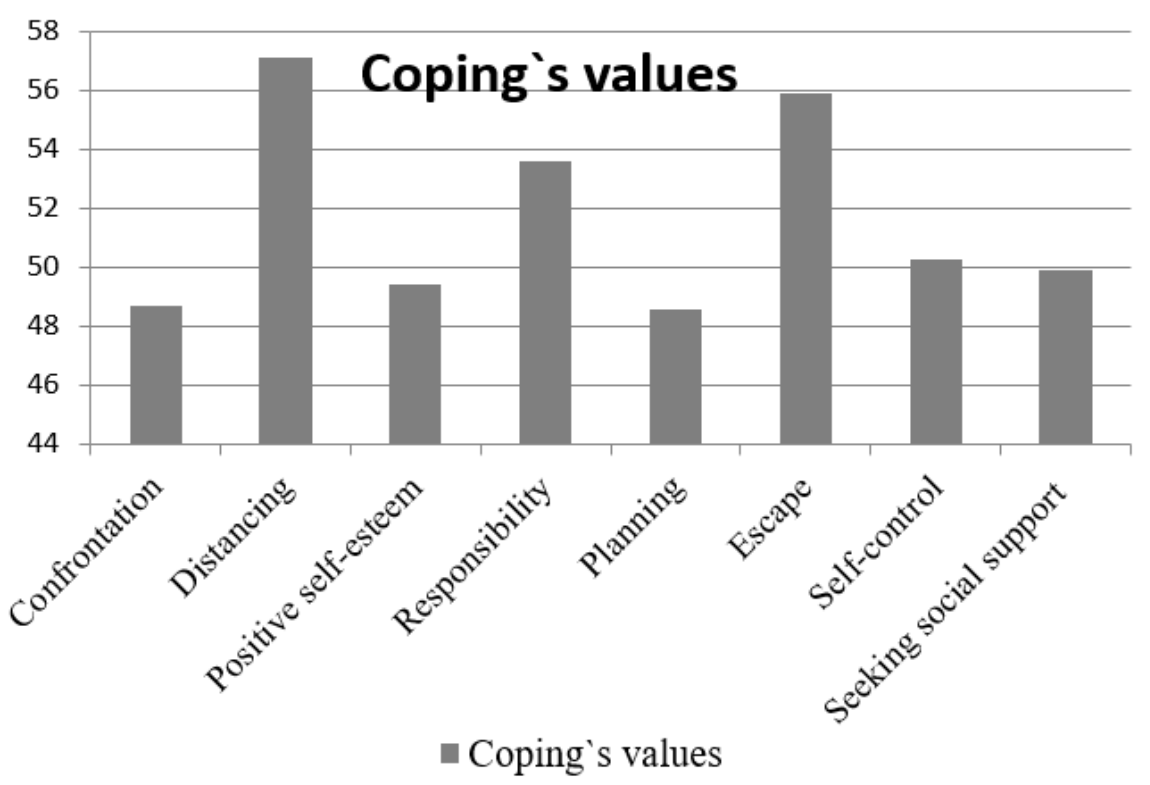

Figure 1 Average Values of Coping Strategies in the Student Group in Distance Learning

In general, according to statistical indicators, the following stress coping strategies have the highest level in the group of students: distancing $\left(\mathrm{x}^{-}=57.1\right)$, responsibility $\left(\mathrm{x}^{-}=53.9\right)$, escape $\left(\mathrm{x}^{-}=55.9\right)$. The lowest level of expression in the group have such copings: confrontation $\left(\mathrm{x}^{-}=48.7\right)$, positive self-esteem $\left(\mathrm{x}^{-}=\right.$ 49.4), planning in solving problems $\left(\mathrm{x}^{-}=48.6\right)$, self-control $\left(\mathrm{x}^{-}=50,3\right)$, seeking 
social support (x (= 49.9). Thus, students during distance learning, on the one hand, tend to take responsibility for learning outcomes in a new format (coping "responsibility"), and on the other - can avoid solving problems (coping "escape") or negate their value "distancing").

On the second stage of the study, the same students were asked to take the method "Scale of Subjective Well-being" to determine the level of subjective well-being. Using multidimensional regression analysis, a statistical model of the influence of students' coping strategies (predictors) on the level of their subjective well-being (dependent variable) was developed.

The following coping strategies were included in the regression model: positive self-esteem; responsibility; planning; escape and self-control (Table 1). These variables had a high statistically significant effect on the experience of emotional comfort by students in distance learning. Other coping strategies were excluded because they did not show a statistically significant effect. The developed statistical model allows to predict the variability of the students subjective well-being depending on the choice of copings by $78.2 \%$ (the reliability of the regression model $\mathrm{R}^{2}=.782$ ).

Table 1 Indicators of the Contribution Degree of Students Coping Strategies in Predicting the Level of Their Subjective Well-being in the Regression Model

\begin{tabular}{|c|c|c|}
\hline Copings (predictors) & $\begin{array}{c}\text { Beta-coefficients (the contribution } \\
\text { of the predictor in predicting the } \\
\text { dependent variable) }\end{array}$ & Significance \\
\hline Positive self-esteem & .483 & .002 \\
\hline Responsibility & -.143 & .000 \\
\hline Planning & .140 & .003 \\
\hline Escape & -.266 & .001 \\
\hline Self-control & .789 & .003 \\
\hline Constant & 7.510 & .000 \\
\hline
\end{tabular}

According to the analyzed data, the most significant positive impact on the level of emotional well-being of distance learning students has a strategy "selfcontrol" ( $\beta=.789)$. This means that students who tend to take control of and manage the situation have a lower level of anxiety about learning outcomes, and therefore show high levels of subjective well-being. This way of overcoming stress allows minimizing anxiety with targeted control of behavior and the ability to self-organize. Our results confirm the research of E. Skinner and his colleagues that adaptive coping strategies are aimed at solving problems and provide a stable psychological state. And maladaptive strategies involve escape from problems and thus determine anxiety and depression (Skinner, Edge, Altman, \& Sherwood, 2003; Cheng, Lau, \& Chan, 2014). 
Such coping strategies as "positive self-esteem" $(\beta=.483)$ and "planning" $(\beta=.140)$ also have a positive effect on increasing the psychological comfort of students. These strategies allow solving problems (in this case, adaptation to distance learning) by purposeful analysis of the situation and analysis of effective behavior, planning activity taking into account the objective conditions and internal resources. Using a tendency to rational planning and self-control, coping "positive self-esteem" allows overcoming negative emotional experiences due to stressful situation through its positive rethinking as an incentive for personal development and new opportunities. For example, distance learning allows using the time spent on the way to university for other types of activity.

The coping mechanisms "escape" $(\beta=-.266)$ and "responsibility" $(\beta=-.143)$ have a negative impact on the students subjective well-being in conditions of distance learning. The impact of coping "escape" on reducing students' psychological comfort is obvious, as this strategy aims to reduce emotional stress by responding to the type of avoidance. However, this form of behavior is infantile and does not solve problems, but only causes them to increase (for example, late completion of educational tasks). As for the "responsibility" strategy, its negative impact on well-being is not so obvious. On the one hand, taking responsibility for the situation is a sign of healthy behavior. However, responsibility is often excessive and is accompanied by components of self-criticism and self-blame. Using this strategy, students can be responsible but feel emotional discomfort and tension.

The results of our study prove the research of I. Arendarchuk and M. Olennikova about the negative impact of maladaptive coping on the students' psychological state in stressful situations (Arendarchuk \& Olennikova, 2015). Our data show that distance learning is as stressful as exams, because this type of learning actualizes coping mechanisms to reduce psychological stress and save emotional health.

The next stage of the study was to determine the types of students in distance learning on the following indicators: the level of psychological comfort, dominant copings and measure of stress tolerance. To do this, the subjects were offered another method "New Stress Tolerance Questionnaire". Using hierarchical cluster analysis, a typology of students according to the level of adaptability was developed. For each type, the average values of each of the indicators were calculated, the differences between which were determined as statistically significant by the criterion of t-Student (Table 2). 
SOCIETY. INTEGRATION. EDUCATION

Proceedings of the International Scientific Conference. Volume VII, May $28^{\text {th }}-29^{\text {th }}$, 2021. 230-238

Table 2 Average Indicators of Coping Strategies, Stress Tolerance and Subjective Wellbeing for Selected Types (clusters) of Students by Level of Adaptability to Distance

\section{Learning}

\begin{tabular}{|c|l|c|c|c|}
\hline \multirow{2}{*}{ Clustering indicators (means) } & \multicolumn{3}{c|}{ Types (clusters) of students } \\
\cline { 2 - 5 } & $1(\mathrm{n}=17)$ & $2(\mathrm{n}=15)$ & $3(\mathrm{n}=20)$ \\
\hline 1 & Stress tolerance & $67.2^{* *}$ & $41.0^{* *}$ & $55.0^{* *}$ \\
\hline 2 & Subjective well-being & $7.0^{* *}$ & $4.6^{* *}$ & $6.3^{* *}$ \\
\hline 3 & Positive self-esteem & $65.7^{*}$ & $46.1^{*}$ & $44.2^{*}$ \\
\hline 4 & Responsibility & $59.3^{*}$ & $51.1^{*}$ & $68.3^{*}$ \\
\hline 5 & Planning & $60.8^{*}$ & $54.3^{*}$ & $52.8^{*}$ \\
\hline 6 & Escape & $41.9^{*}$ & $61,5^{*}$ & $47.5^{*}$ \\
\hline 7 & Self-control & $57.6^{*}$ & $42.6^{*}$ & $61.4^{*}$ \\
\hline
\end{tabular}

Note: Differences in mean values at significant level $p \leq 0.05^{*}, p \leq 0.01 * *$

In general, three types (clusters) of students in distance conditions were identified:

1) adaptive type (high indicators of well-being $(\overline{\mathrm{x}}=7)$, high indicators of tolerance to stress $(\overline{\mathrm{x}}=67.2)$, dominant strategies "positive self-esteem" $(\overline{\mathrm{x}}=65.7)$, “responsibility” ( $\overline{\mathrm{x}}=59.3)$ and “planning” $(\overline{\mathrm{x}}=60.8)$;

2) maladaptive type (low indicators of well-being $(\bar{x}=4.6)$, low indicators of tolerance to stress $(\overline{\mathrm{x}}=41)$ and "positive self-esteem" $(\overline{\mathrm{x}}=46.1)$, dominant coping "escape" ( $\overline{\mathrm{x}}=61.5)$;

3) average adaptive type (average indicators of well-being $(\overline{\mathrm{x}}=6.3)$, average indicators of tolerance to stress $(\overline{\mathrm{x}}=55)$; dominant strategies "responsibility" ( $\overline{\mathrm{x}}=68.3)$, "self-control" ( $\overline{\mathrm{x}}=61.4)$, low indicators of coping "positive self-esteem" ( $\overline{\mathrm{x}}=44.2)$.

The subjects of 1 cluster (adaptive type) feel most comfortable in distance learning at the university and have a high level of stress resistance. Due to the dominance of coping "positive self-esteem", "responsibility" and "planning" students of this type are quite labile, able to adapt to new changes, effortlessly go beyond the accepted limits, have harmony and comfort in the emotional sphere of life.

Subjects from cluster 2 (maladaptive type) feel very uncomfortable in distance learning at the university and have a low level of resilience to stress. They are characterized by an escape strategy; they tend to avoid solving problems, are not inclined to plan or adapt to new conditions, and tend to be dissatisfied with their own lives.

Subjects from cluster 3 (average adaptive type) are characterized by an average level of subjective well-being in distance learning. This type includes students who try to take responsibility for the situation, but often blame 
themselves for failures and feelings of guilt. This can cause psychological discomfort in students.

Thus, the classification of students into such types according to the level of adaptability once again confirms the view that adaptive coping strategies not only avoid psychological problems, but also help to improve academic performance and increase resistance to stress (Freire, Mar Ferradás, Regueiro, \& Rodríguez 2020).

\section{Conclusion}

Coping strategies are emotional and cognitive-behavioral mechanisms that allow individuals to manage with various life difficulties and become relevant in stressful circumstances. Coping allows students to deal with learning activities and unusual situations that arise in the educational process. One of such situations is a new format of distance learning for students, which involves the actualization of internal resources and the choice of specific ways of adaptation to new conditions.

The study analyzed the coping strategies of students, which they use to cope with stress in distance learning, and their impact on the level of students subjective well-being. Using regression analysis, a statistic model for predicting the psychological comfort of students was determined, depending on the choice of coping. The following coping strategies were included in the regression model: positive self-esteem; responsibility; planning; escape and self-control. Positive self-esteem, planning and self-control have a positive effect on emotional wellbeing, but strategies escape and responsibility reduce the psychological comfort of students.

Using hierarchical cluster analysis, three types of students were identified according to the level of adaptability to distance learning: 1) adaptive type (high level of subjective well-being, high stress resistance, positive self-esteem, tendency to self-control and planning in stressful conditions); 2) maladaptive type (low indicators of well-being and tolerance to stress, tendency to avoid solving problems); 3) average adaptive type (average level of psychological comfort and tolerance to stress; tendency to take responsibility for the situation, connected with excessive self-criticism).

Further research can be aimed at identifying statistically significant differences in the choice of coping strategies by students in the usual learning conditions and in stressful conditions (the situation of quarantine and distance learning). 


\section{References}

Arendarchuk, Y. V. (2015). Kopynh-stratehyy studentov kak faktory` preodolenyia ryskov obrazovatelnoi sredy` VUZa. Natsyonalnaia assotsyatsyia ucheny $k h$, 87-90.

Cheng, C., Lau, H.-P., \& Chan, M. (2014). Coping flexibility and psychological adjustment to stressful life changes: a meta-analytic review. Psychological Bulletin, 140, 1582-1607. https://doi.org/10.1037/a0037913

Deasy, C., Coughlan, B., Pironom, J., Jourdan, D., \& Mannix-McNamara, P. (2014). Psychological distress and coping amongst higher education students: a mixed method enquiry. PLoS ONE, 9(12). https://doi.org/10.1371/journal.pone.0115193

Dermanova, Y. B. (2011). Sovladaiushchee povedenye kak mekhanyzm razvytyia lychnosty v peryod rannei vzroslosty. Vestnyk Sankt-Peterburhskoho unyversyteta, 12, 85-96.

Fetyskyn, N. P., Kozlov, V. V., \& Manuilov, H. M. (2002). Shkala sub`ektyvnoho blahopoluchyia. Sotsyalno-psykholohycheskaia dyahnostyka razvytyia lychnosty y maly `hh hrupp, 467-470.

Freire, C., Mar Ferradás, M., Regueiro, B., \& Rodríguez, S. (2020). Coping Strategies and SelfEfficacy in University Students: A Person-Centered Approach. Educational Psychology. Retrieved from https://www.frontiersin.org/articles/10.3389/fpsyg.2020.00841/full

Galatzer-Levy, I. R., Burton, C. L., \& Bonanno, G. A. (2012). Coping flexibility, potentially traumatic life events, and resilience: a prospective study of college student adjustment. $J$. Soc. Clin. Psychol, 31, 542-567. https://doi.org/10.1521/jscp.2012.31.6.542

Kyreeva, V. M. (2012). Vedushchye kopynh-stratehyy studentov s razlychny`m urovnem stressoustoichyvosty. Nauchny`e vedomosty. Humanytarny`e nauky, 6, 229-233.

Kornylova, T. V. (2010). Novy i oprosnyk tolerantnosty-yntolerantnosty k neopredelennosty. Psykholohycheskyi zhurnal, 1, 74-86.

Kriukova, T.L., \& Kuftiak, E.V. (2007). Oprosnyk sposobov sovladanyia (adaptatsyia metodyky WCQ). Zhurnal praktycheskoho psykholoha, 3, 93-112.

Kriukova, T. L. (2008). Chelovek kak subekt sovladaiushcheho povedenyia. Sovladaiushchee povedenye: sovremennoe sostoianye y perspektyvy`. 55 - 67.

Olennykova, M. V. (2015). Kopynh-stratehyy studentov v sytuatsyy e`kzamena. Voprosy` metodyky prepodavanyia $v$ vuze, 75-83.

Skinner, E. A., Edge, K., Altman, J., \& Sherwood, H. (2003). Searching for the structure of coping: A review and critique of category systems for classifying ways of coping. Psychol. Bull, 129, 216-269. https://doi.org/10.1037/0033-2909.129.2.216 